\title{
ANALISIS SPASIAL DAERAH BANJIR MENGGUNAKAN HEC-RAS DAN QGIS UNTUK SUB DAS BABURA
}

\section{Meinarty Sinurat, Ahmad Perwira Mlia, Muhammad Faisal}

Universitas Sumatera Utara, Indonesia

Email: mei.sinurat.ms@gmail.com,a.perwira.mulia@gmail.com,mfaisal@usu.ac.id

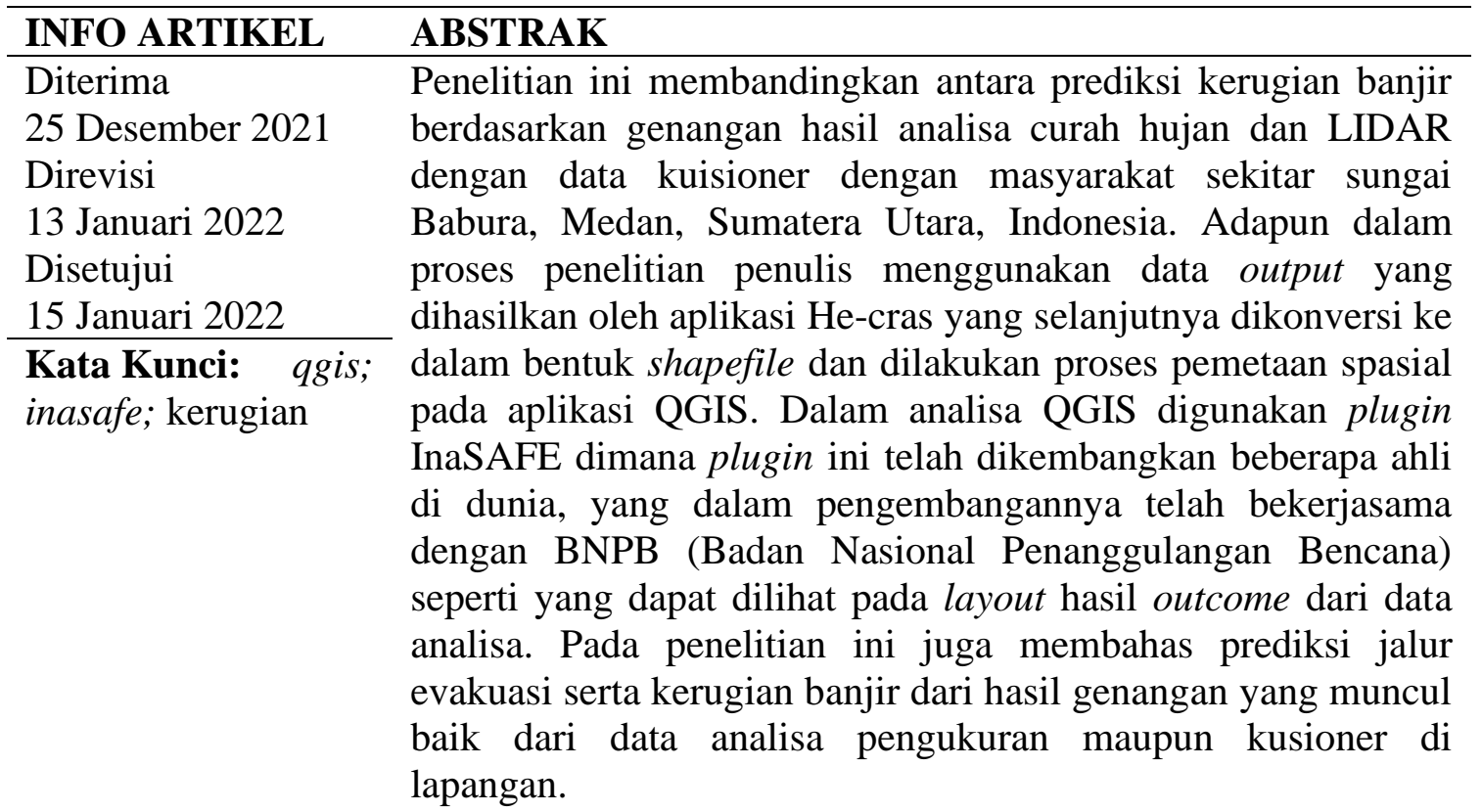

\section{ABSTRACT}

This study compares flood loss predictions based on inundation results from rainfall analysis and LIDAR with questionnaire data with communities around the Babura river, Medan, North Sumatra, Indonesia. As for the research process, the author uses the output data generated by the He-cras application which is then converted into shapefile form and a spatial mapping process is carried out in the QGIS application. In the QGIS analysis, the InaSAFE plugin is used where this plugin has been developed by several experts in the world, who in its development have collaborated with BNPB (National Disaster Management Agency) as can be seen in the layout of the results of the analysis data. This study also discusses the prediction of evacuation routes and flood losses from inundation results that

Keywords: $\quad$ qgis; arise from both measurement analysis data and questionnaires inasafe; losses in the field.

$\begin{array}{ll}\text { How to cite: } & \text { Sinurat, M., Ahmad Perwira Mlia, Muhammad Faisal (2022) Analisis Spasial Daerah Banjir } \\ & \text { Menggunakan Hec-Ras dan QGIS untuk Sub Das Babura, Jurnal Syntax Admiration 3(1). } \\ & \text { https://doi.org/10.46799/jsa.v3i1.382 } \\ \text { E-ISSN: } & 2722-5356 \\ \text { Published by: } & \text { Ridwan Institute }\end{array}$




\section{Pendahuluan}

Banjir menjadi salah satu bencana yang paling sering terjadi dan menimbulkan banyak kerugian dalam masyarakat, baik dalam bidang ekonomi, kesehatan maupun kehidupan sosial. Adanya bencana banjir yang berkala sedikit banyak memberikan pengalaman bagi masyarakat untuk menghadapi dan mengatasinya. Dalam tulisan ini akan dibahas bagaimana genangan yang diakibatkan luapan banjir sungai merugikan insfrastruktur di masyarakat serta jalur evakuasi saat terjadinya banjir (Santoso \& Taufik, 2010).

Penelitian ini akan membahas salah satu sungai yang berada di kota Medan yaitu sungai Babura, dimana keberadaannya melintasi titik-titik pemukiman penduduk, daerah perdagangan, perkuliahan dan pemerintahan. Sudah banyak hal yang dilakukan pemerintah dalam penanggulangan bencana banjir, diantaranya pemerintah kota medan telah menentukan daerah titik shelter saat terjadi bencana. Dalam penelitian ini Penulis membahas bagaimana jalur tercepat yang ditempuh masyarakat saat terjadi banjir dalam skala tahunan tertentu, menuju titik shelter yang telah ditentukan sesuai info dari geoportal Medan. Hasil dari analisis (Irianingsih \& Sukono, 2017) menunjukkan bahwa besarnya nilai kerugian lebih dipengaruhi oleh jumlah kerusakan rumah, sedangkan faktor lainnya tidak berpengaruh secara signifikan.

Seperti hal nya hasil simulasi menunjukkan bahwa luas area dan durasi banjir akan meningkat dengan bertambahnya periode ulang (Muin et al., 2015), dengan menggunakan metode perhitungan nilai pasar akan diperoleh estimasi kerugian ekonomi yang dialami masyarakat yang tinggal di sepanjang bantaran SubDAS (Hutauruk et al., 2020).

Dalam penentuan jalur evakuasi banjir tersebut akan diolah dengan QGIS (Quantum Geographical Information System) (Isma'il \& Saanyol, 2013). Dimana data banjir yang digunakan telah diperoleh dari hasil perhitungan curah hujan dan data LIDAR disekitar daerah penelitian. Menggunakan model genangan berbasis GIS untuk menghasilkan peta genangan untuk diberikan kejadian banjir pesisir baik di bawah kondisi lingkungan saat ini dan skenario masa depan perubahan lingkungan. Dalam kondisi saat ini, perkiraan paparan kerusakan akibat banjir ekstrem ini acara sudah tinggi, di ca. €4,0 miliar (untuk acara 1:100 tahun) dan €5,2 miliar (untuk 1:1.000 peristiwa tahun), sesuai dengan ca. 1,2 dan 1,5\%, masing-masing, dari PDB Indonesia 912 Bahaya Nat (2011) 56:899-916 123 pada tahun 2008. (Ward et al., 2011) tidak begitu berbeda yang digunakan dalam penelitian (Suprajaka \& Putri, 2018) terdiri dari: skoring tingkat klasifikasi bencana banjir dan valuasi ekonomi. Spatial Gap Analysis/Overlay.

Dengan mensimulasikan aliran banjir dengan kala ulang 10, 25, 50, 100, dan 1000 tahun menggunakan HEC- RAS dengan simulasi steadyflow. (Demir \& Kisi, 2016) Peta menunjukkan pada banjir kala ulang 10 tahun, ketinggian banjir mencapai 6,2 m dengan daerah yang tergenang sekitar 30\% di wilayah hilir sungai. Pada kala ulang 100 tahun, ketinggian banjir mencapai 7,6 m dengan daerah yang tergenang sekitar $60 \%$. 


\section{Metode Penelitian}

1. Lokasi Penelitian

Lokasi penelitian ini berada pada DAS Babura yang merupakan salah satu anak sungai dari Sungai Deli (DAS Deli) yang terbentang dari kawasan Sibolangit (Kabupaten Deli Serdang) hingga Kota Medan dengan luas $98 \mathrm{~km}^{2}$ (BPDAS Wampu Sei Ular, 2012). Daerah Aliran Sungai Babura terbentang antara $3^{\circ} 25^{\prime} 12.48^{\prime \prime}$ 3³5'27.84” Lintang Utara dan 98 32’37.12” - 98 40’20.18” Bujur Timur. Adapun batas Sungai Babura adalah:

- Sebelah Utara: Kota Medan, Selat Malaka.

- Sebelah Timur: Kota Medan.

- Sebelah Selatan: Kabupaten Deli Serdang.

- Sebelah Barat: Kabupaten Deli Serdang dan Kota Medan.

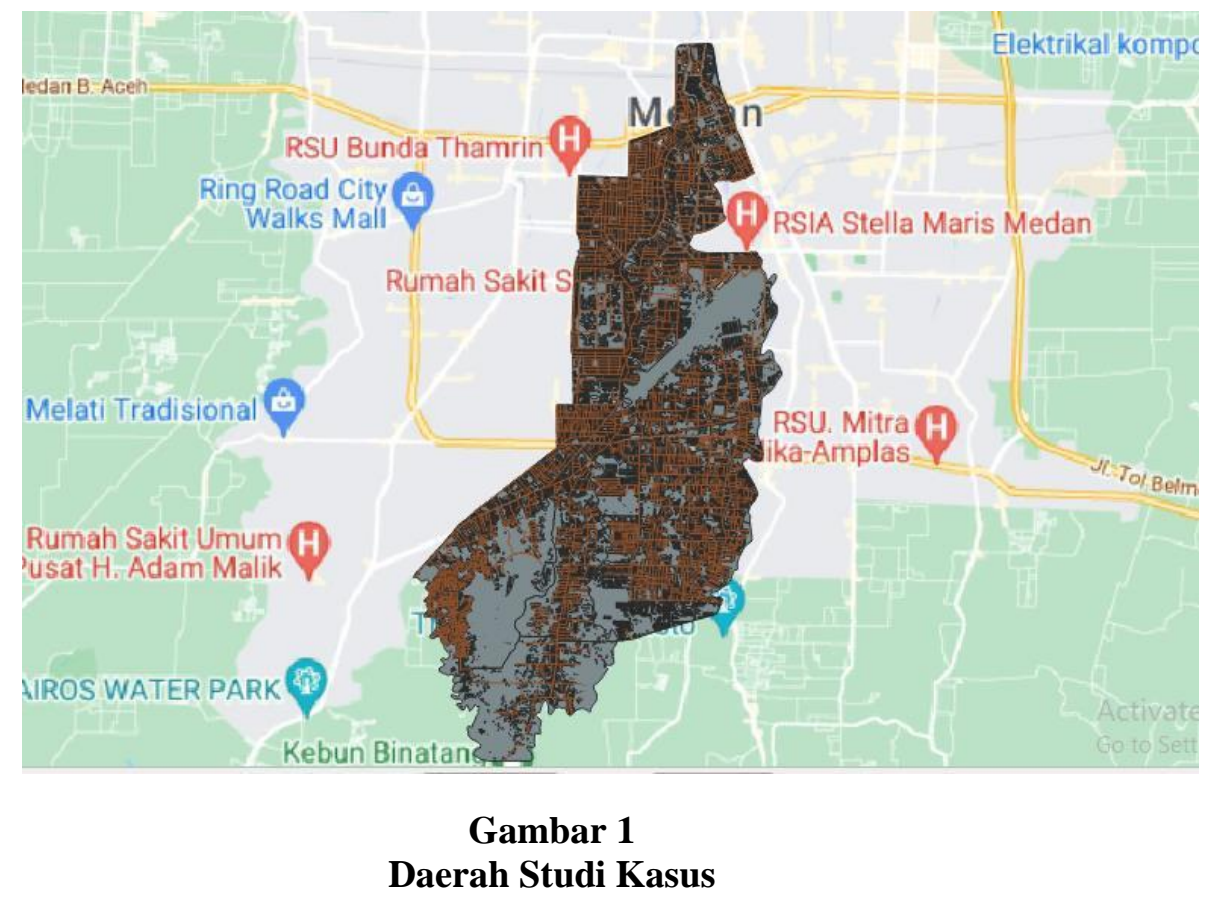

2. Data dan Alat Penelitian

Data yang digunakan dalam penelitian ini adalah data sekunder yaitu data yang diperoleh dari instansi-instansi yang terkait dalam penelitian ini. Adapun data sekunder dalam penelitian ini adalah:

1. Data curah hujan bulanan dan harian maksimum tahun 2010 - 2019 yang diperoleh dari Stasiun Klimatologi Sampali Medan.

2. Peta digital DAS Babura diperoleh dari BPDAS Sei Wampu Ular.

3. Peta digital Kota Medan dan tata guna lahan diperoleh dari BAPPEDA Kota Medan.

4. Data Digital Elevation Model (DEM) SRTM 30 m dari http://earthexplorer.usgs.gov. 
5. Data profil memanjang (Long Section) sungai dan melintang (Cross Section) sungai serta data elevasi dan kemiringan sungai yang diperoleh dari Balai Wilayah Sungai Sumatera-II (BWSS-II).

Dalam menganalisis data-data di atas digunakan suatu perangkat alat berupa perangkat keras (Hardware) dan perangkat lunak (Software) yang dimulai dari pemasukan data (Input) sampai dengan pencetakan hasil (Output). Dimana perangkat keras (Hardware) terdiri dari: Komputer, printer, dan alat tulis. Sementara perangkat lunak (Software) terdiri dari: Microsoft Office, Microsoft Excel, HEC - RAS, GIS, dan Google Earth.

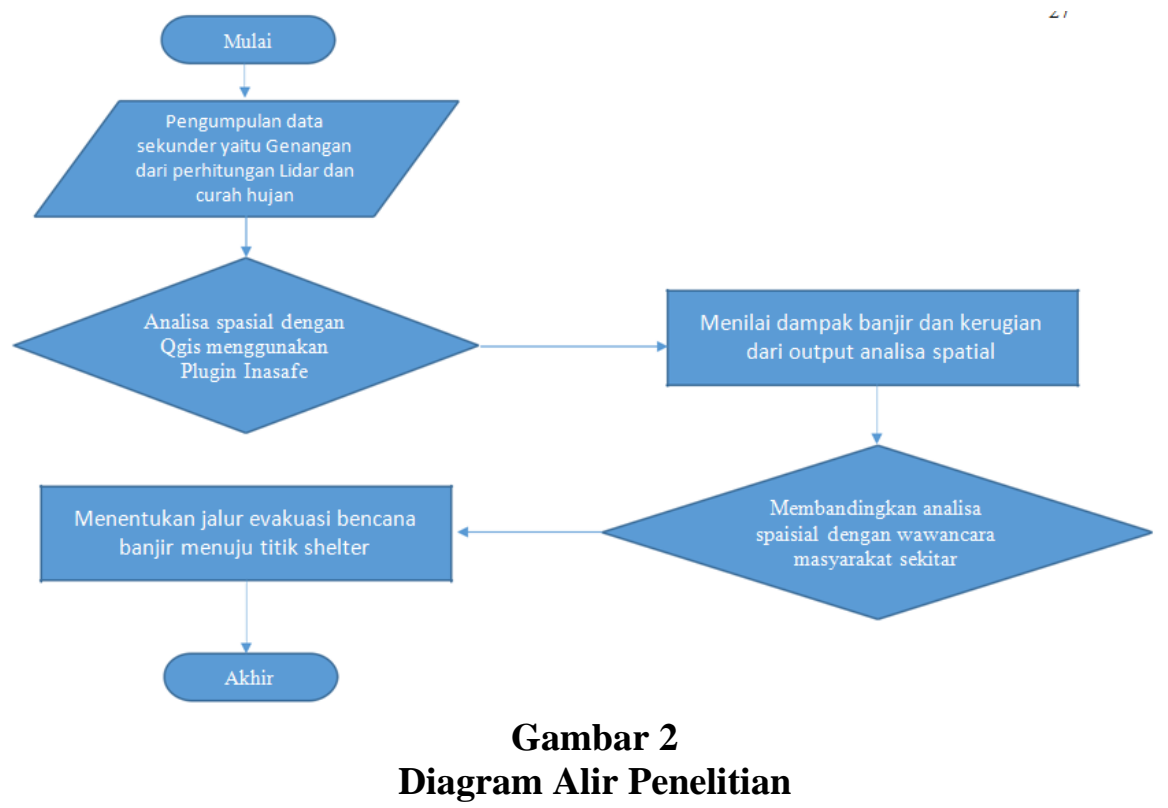


Analisis Spasial Daerah Banjir Menggunakan Hec-Ras dan QGIS untuk Sub Das

Babura

\section{Hasil dan Pembahasan}

\section{Data Genangan Banjir Sungai Babura}

Adapun genangan sesuai periode berkala dari output analisa HE-CRas sebagai berikut :

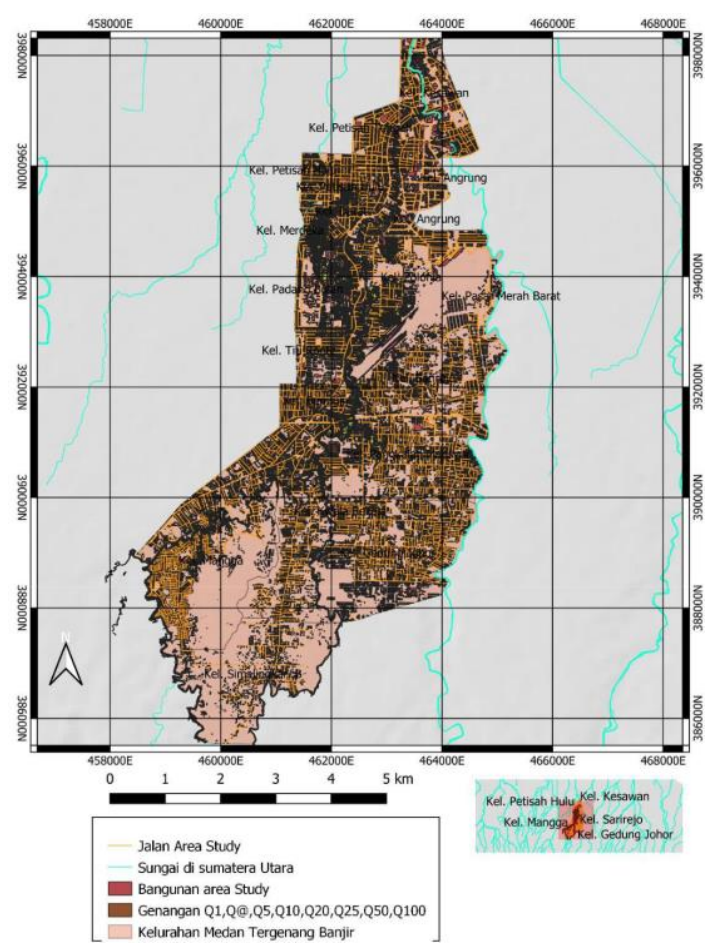

Gambar 3

Genangan dan SudyArea
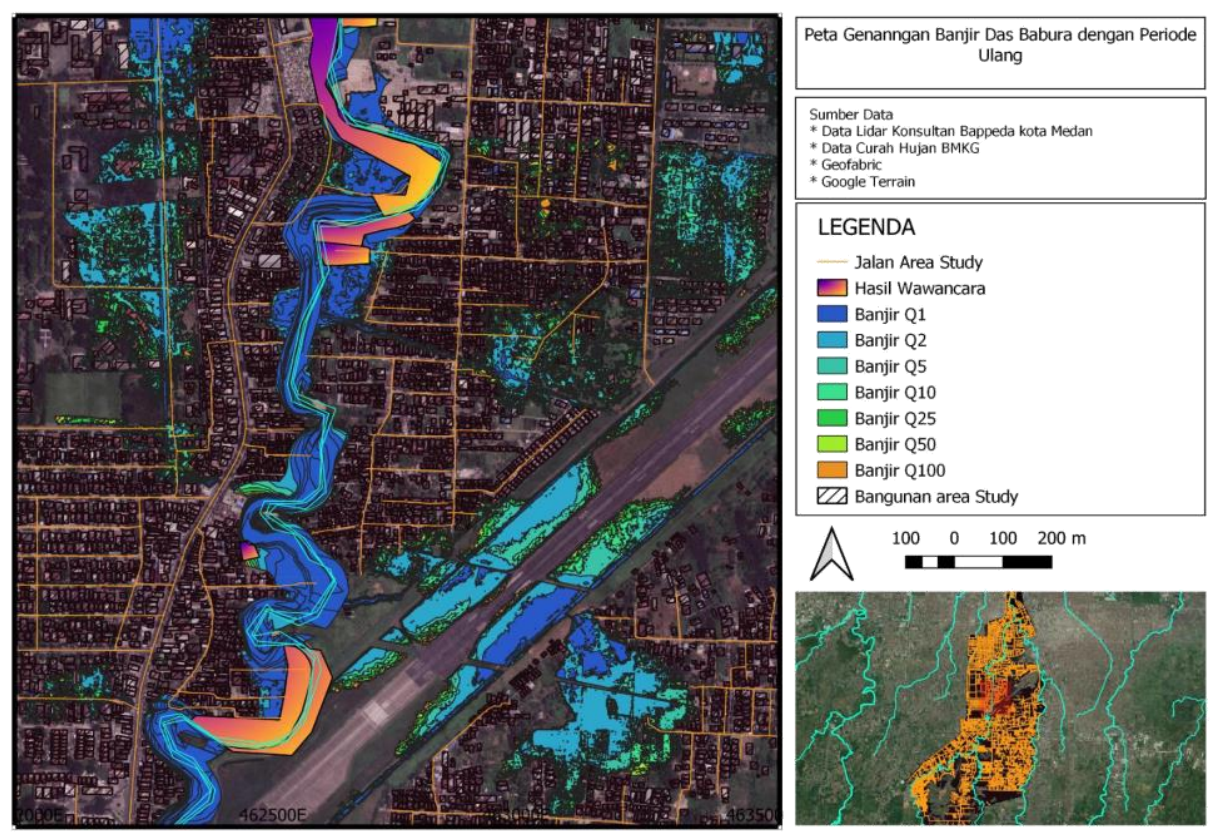

Gambar 4

Genangan Dan Periode Ulang 


\section{Analisa Spasial dengan InaSAFE}

Adapun data genangan tiap periode berkala tersebut selanjutnya diolah dalam program QGIS menggunakan Plugin InaSAFE dan menghasilkan data-data genangan banjir pada bangunan dan jalan di area penelitian seperti berikut :

Tabel 1

Tabel Jumlah Bangunan Dan Jalan Tergenang

\begin{tabular}{lcccccccc}
\hline $\begin{array}{l}\text { Debit Banjir } \\
\text { Periode }\end{array}$ & Q100 & Q50 & Q25 & Q20 & Q10 & Q5 & Q2 & Q1 \\
\hline $\begin{array}{l}\text { Bangunan } \\
\text { RSS (m2) }\end{array}$ & 37848 & 36967 & 35375 & 34704 & 33471 & 32055 & 30351 & 26779 \\
\hline $\begin{array}{l}\text { Bangunan } \\
\left.\text { RS (m }{ }^{2}\right)\end{array}$ & 165337 & 161255 & 155039 & 152221 & 147465 & 141630 & 130449 & 105781 \\
\hline $\begin{array}{l}\text { Bangunan } \\
\text { Mewah (m2) }\end{array}$ & 146689 & 141091 & 132938 & 131090 & 128485 & 123091 & 118500 & 100313 \\
\hline Total & 349.874 & 339.313 & 323.352 & 318.015 & 309.421 & 296.776 & 279.300 & 232.873 \\
\hline $\begin{array}{l}\text { Bangunan } \\
\text { RSS (unit) }\end{array}$ & 677 & 663 & 635 & 624 & 603 & 581 & 553 & 491 \\
\hline $\begin{array}{l}\text { Bangunan } \\
\text { RS (unit) }\end{array}$ & 1022 & 994 & 959 & 943 & 914 & 880 & 814 & 666 \\
\hline $\begin{array}{l}\text { Bangunan } \\
\text { Mewah (unit) }\end{array}$ & 189 & 177 & 171 & 168 & 163 & 153 & 144 & 112 \\
\hline Jalan (m $\left.{ }^{2}\right)$ & 3801 & 3528 & 3260 & 3120 & 2896 & 2678 & 2379 & 1976 \\
\hline
\end{tabular}

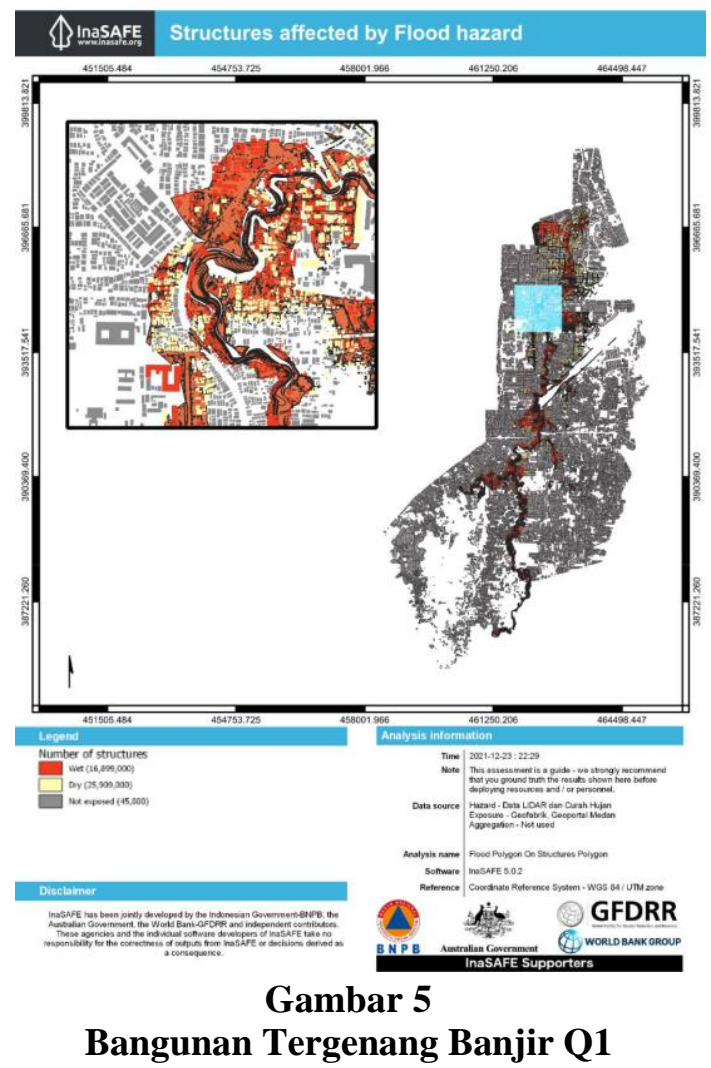




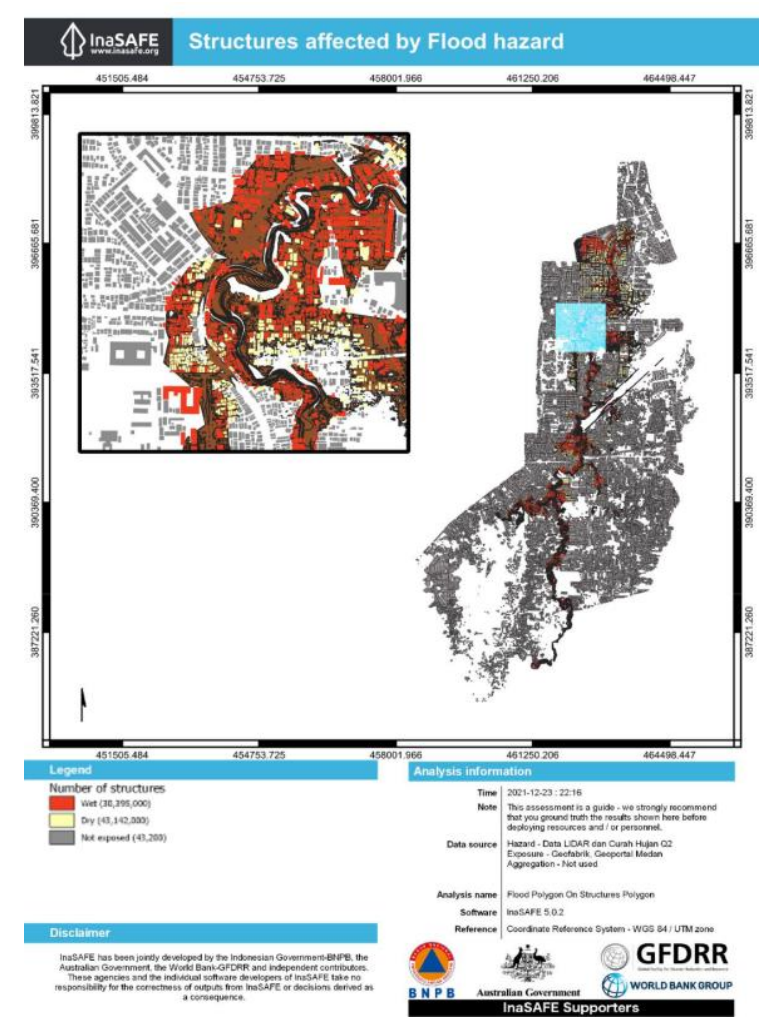

Gambar 6

Bangunan Tergenang Banjir Q2

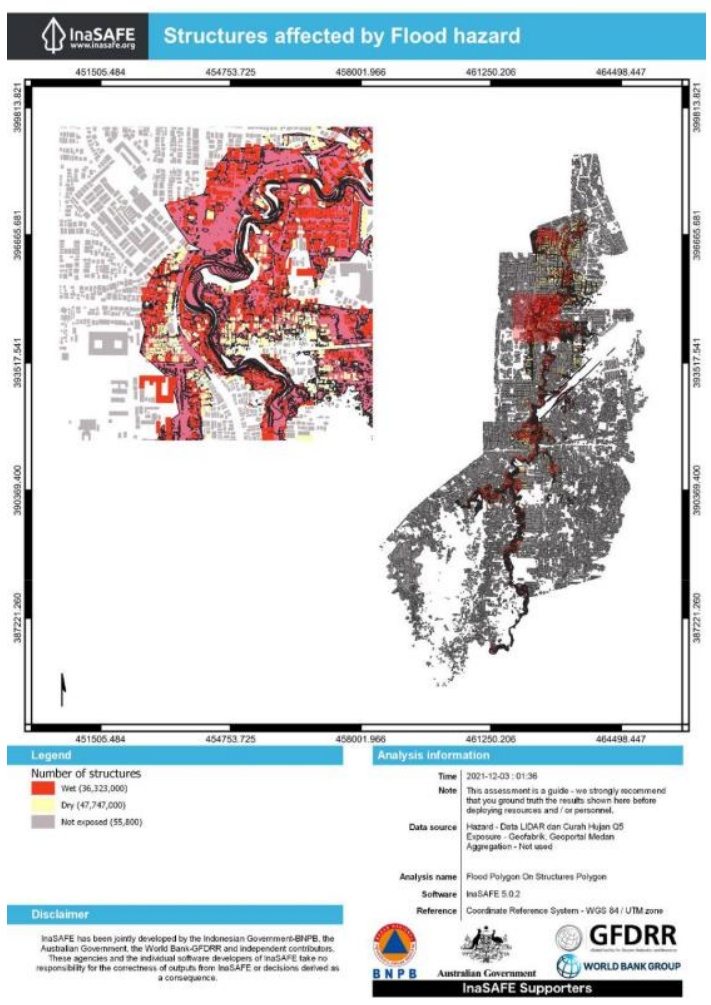

Gambar 7

Bangunan Tergenang Banjir Q5 
Meinarty Sinurat, Ahmad Perwira Mlia, Muhammad Faisal

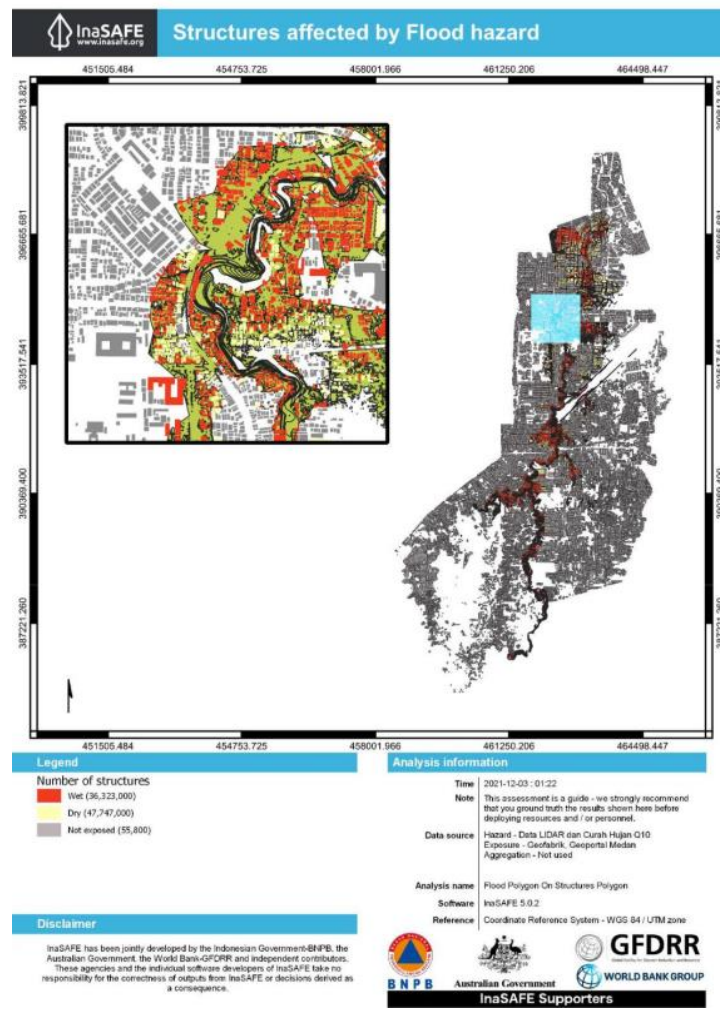

Gambar 8

Bangunan Tergenang Banjir Q10

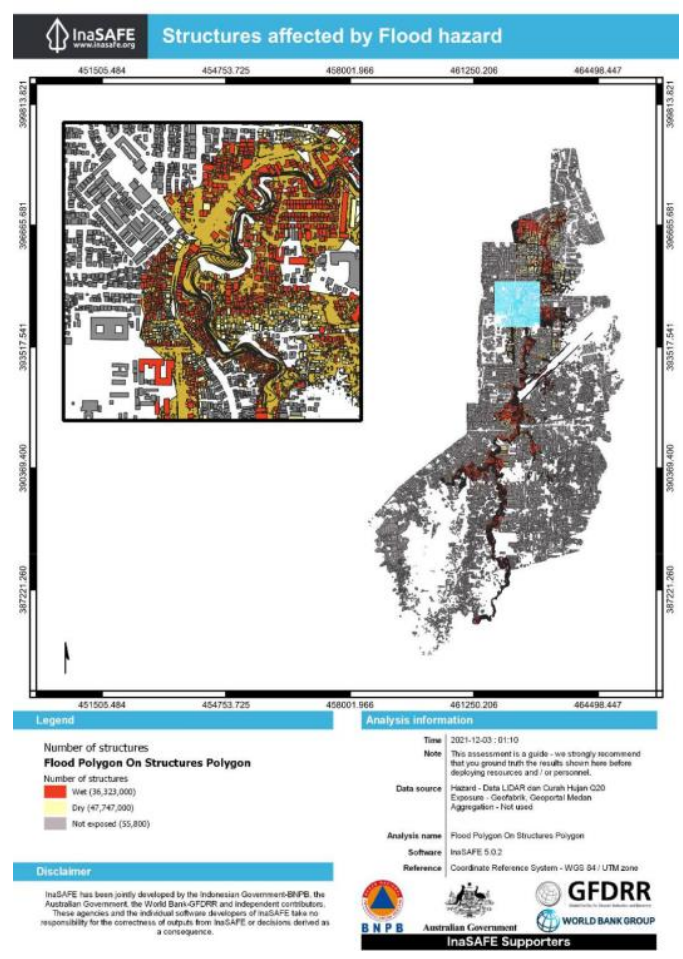

Gambar 9

Bangunan Tergenang Banjir Q20 
Analisis Spasial Daerah Banjir Menggunakan Hec-Ras dan QGIS untuk Sub Das

Babura

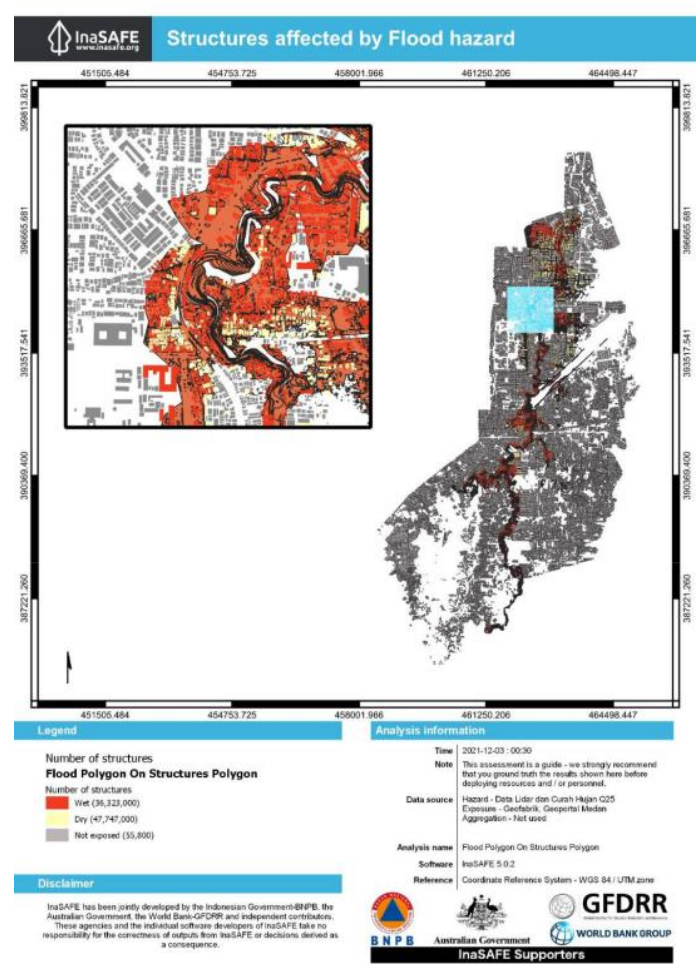

Gambar 10

Bangunan Tergenang Banjir Q25

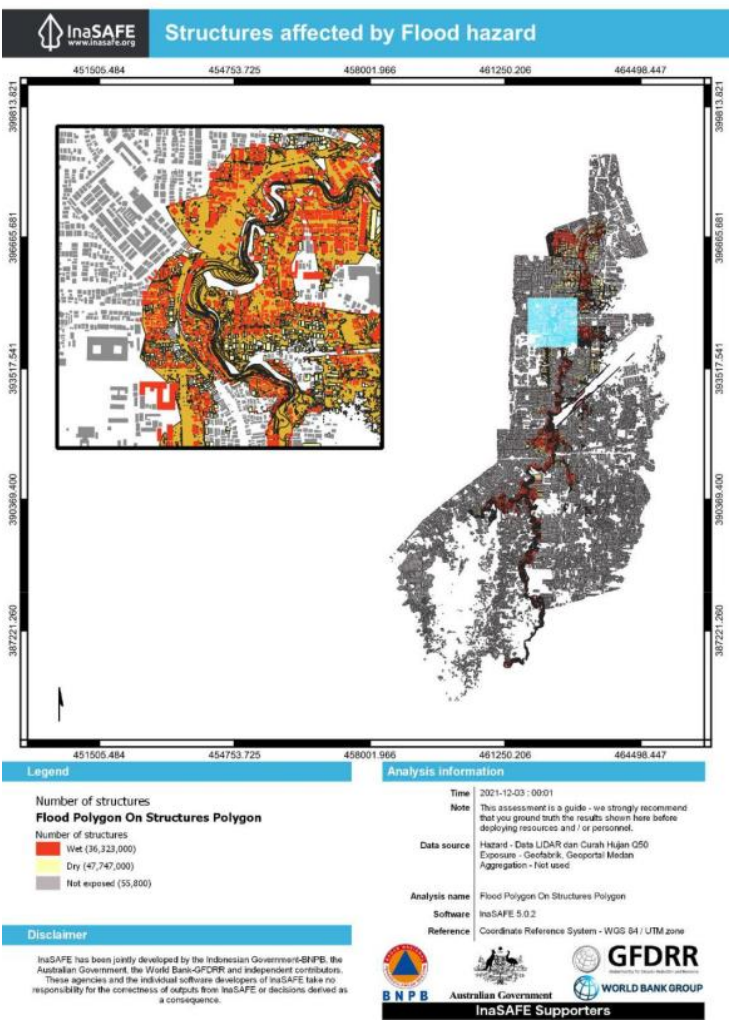

Gambar 11

Bangunan Tergenang Banjir Q50 
Meinarty Sinurat, Ahmad Perwira Mlia, Muhammad Faisal

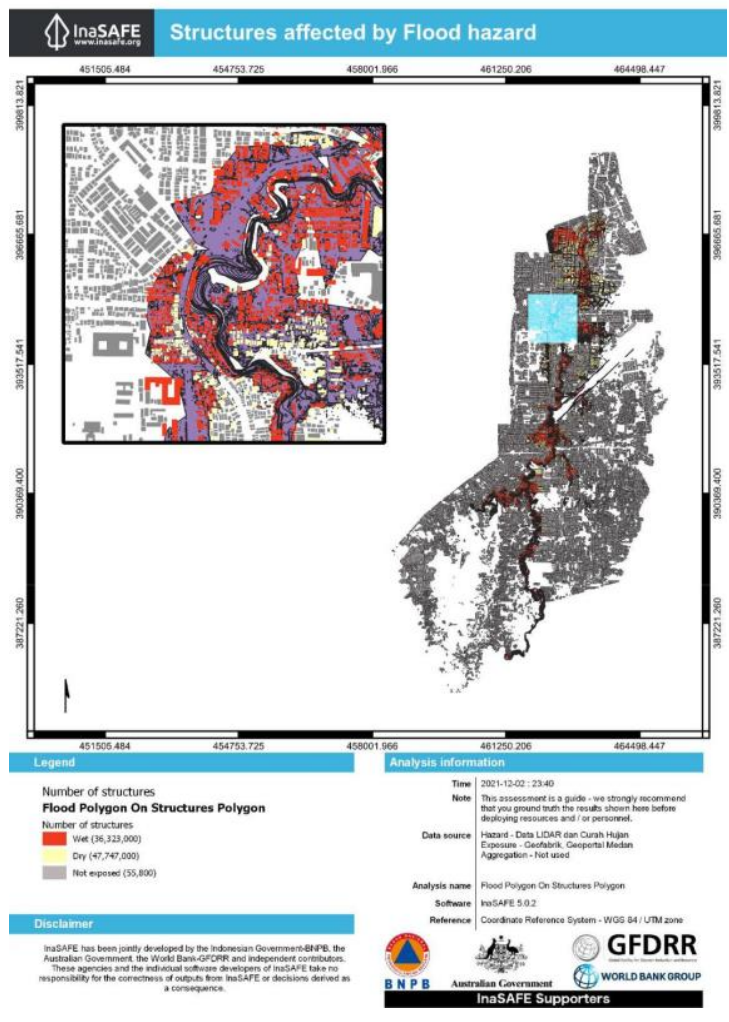

Gambar 12

Bangunan Tergenang Banjir Q100

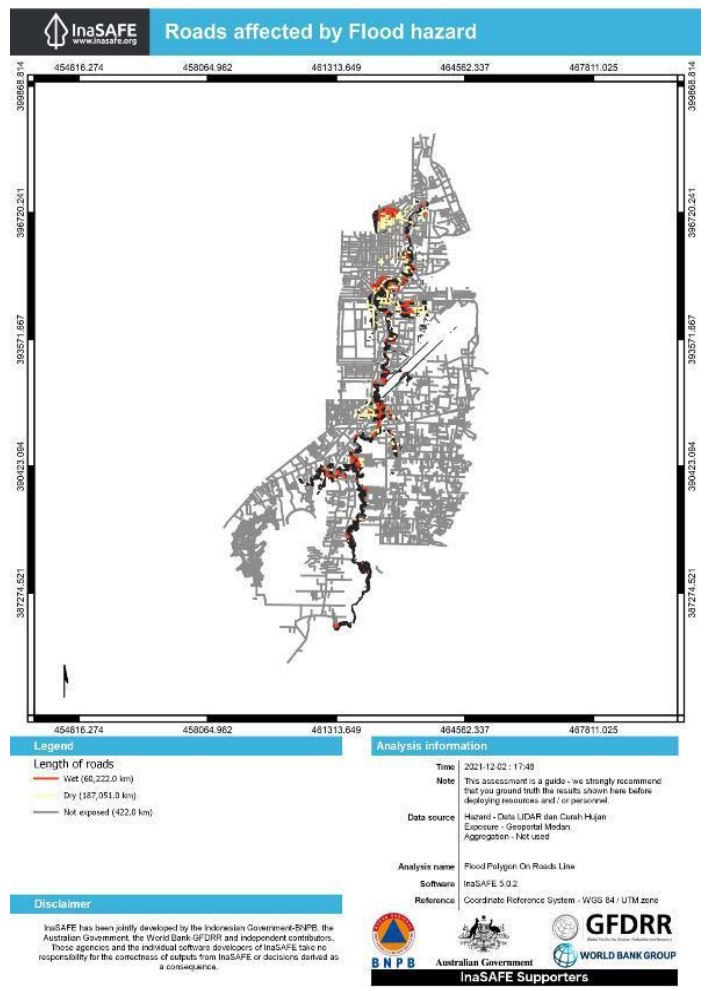

Gambar 13

Jalan Tergenang Banjir Q1 
Analisis Spasial Daerah Banjir Menggunakan Hec-Ras dan QGIS untuk Sub Das

Babura

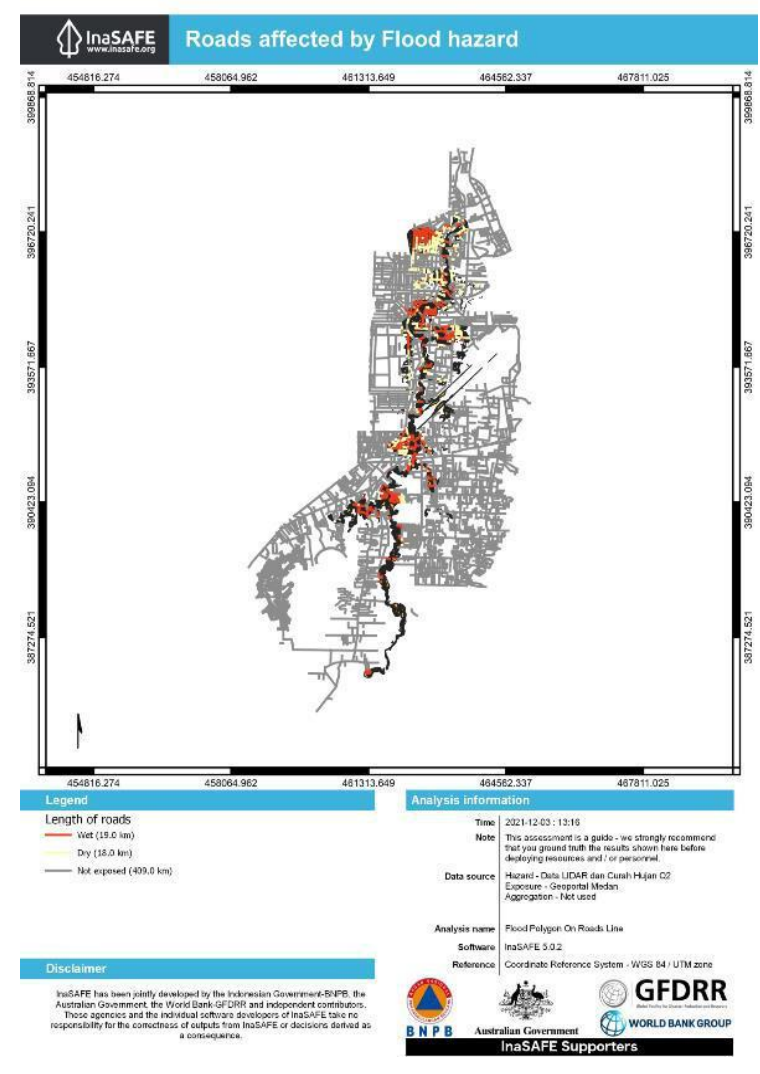

Gambar 14

Jalan Tergenang Banjir Q2

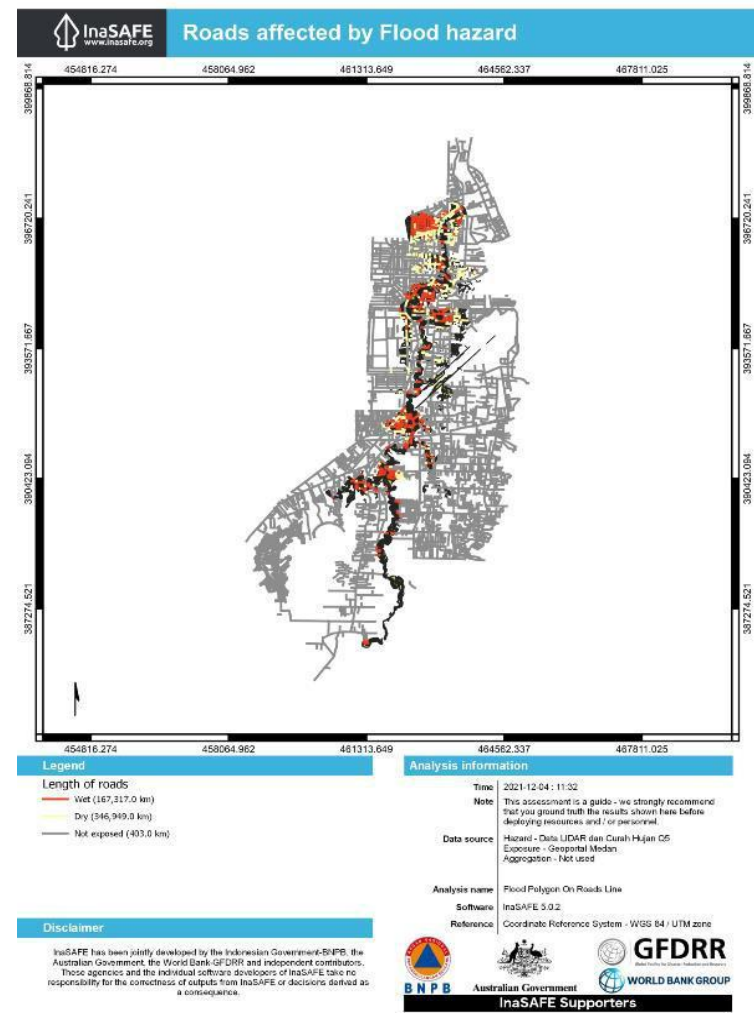

Gambar 15

Jalan Tergenang Banjir Q5 
Meinarty Sinurat, Ahmad Perwira Mlia, Muhammad Faisal
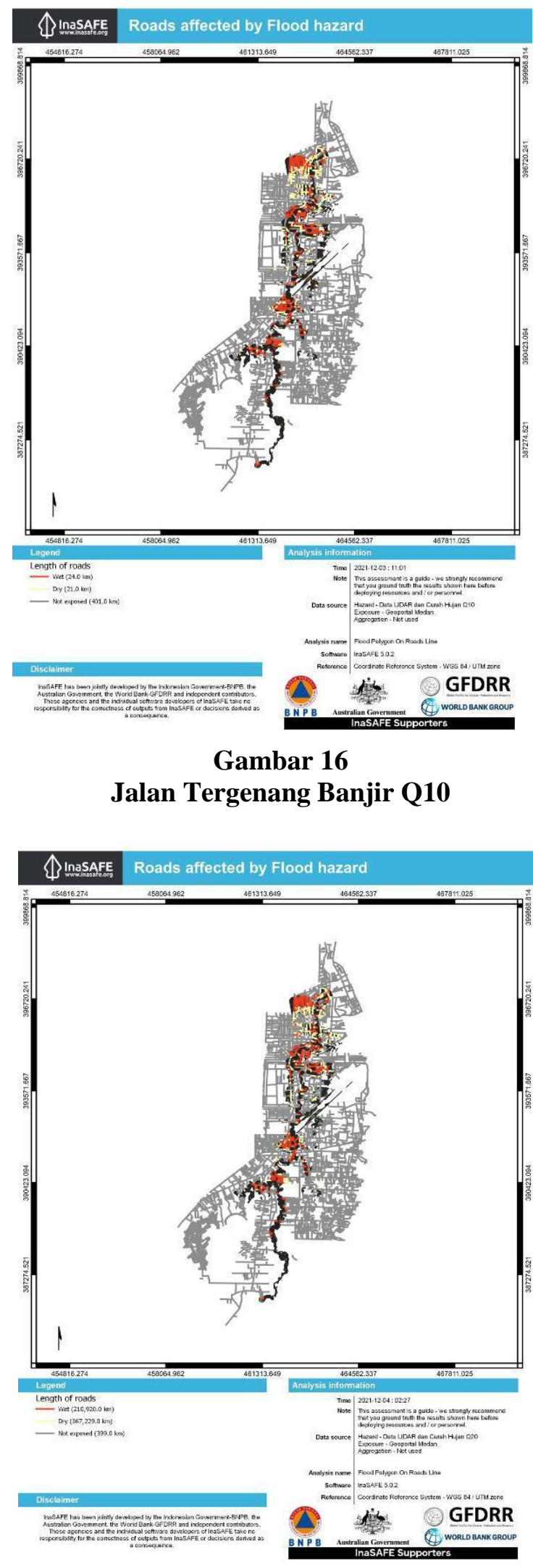

Gambar 17

Jalan Tergenang Banjir Q20 
Analisis Spasial Daerah Banjir Menggunakan Hec-Ras dan QGIS untuk Sub Das

Babura

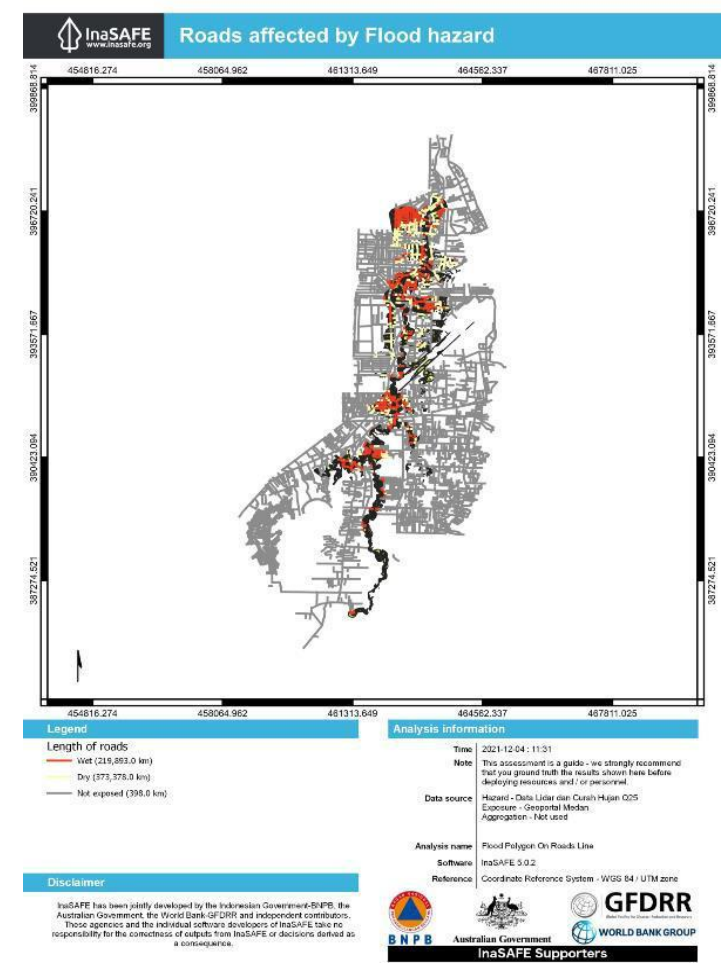

Gambar 18

Jalan Tergenang Banjir Q25

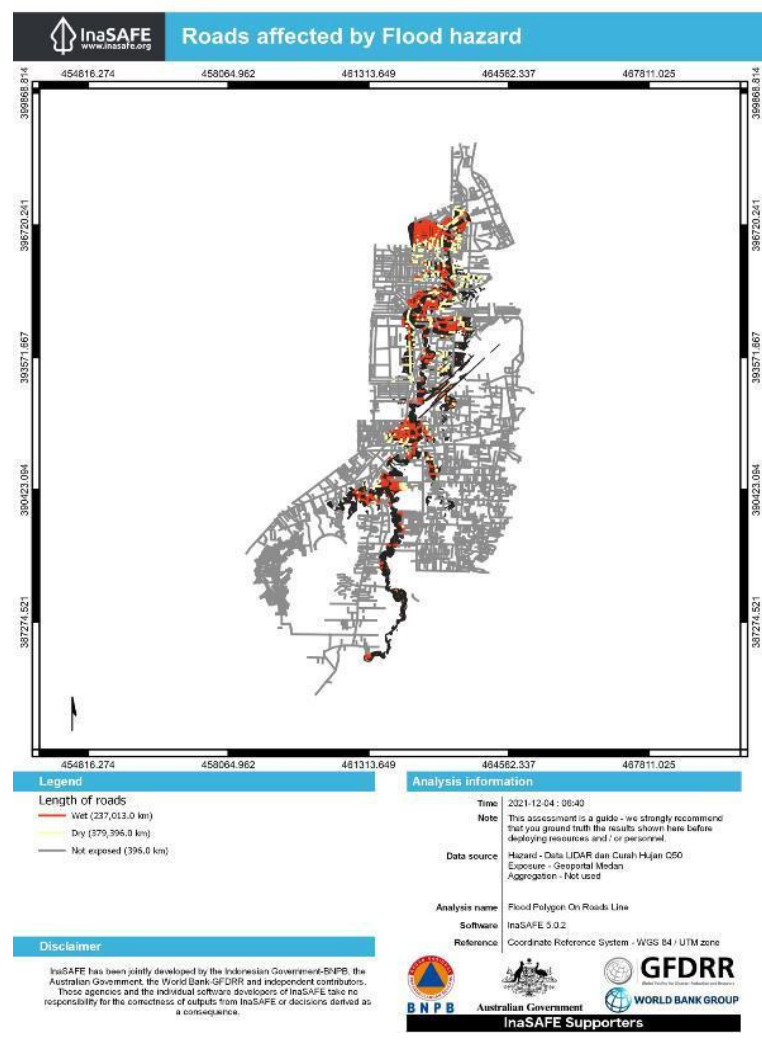

Gambar 19

Jalan Tergenang Banjir Q50 


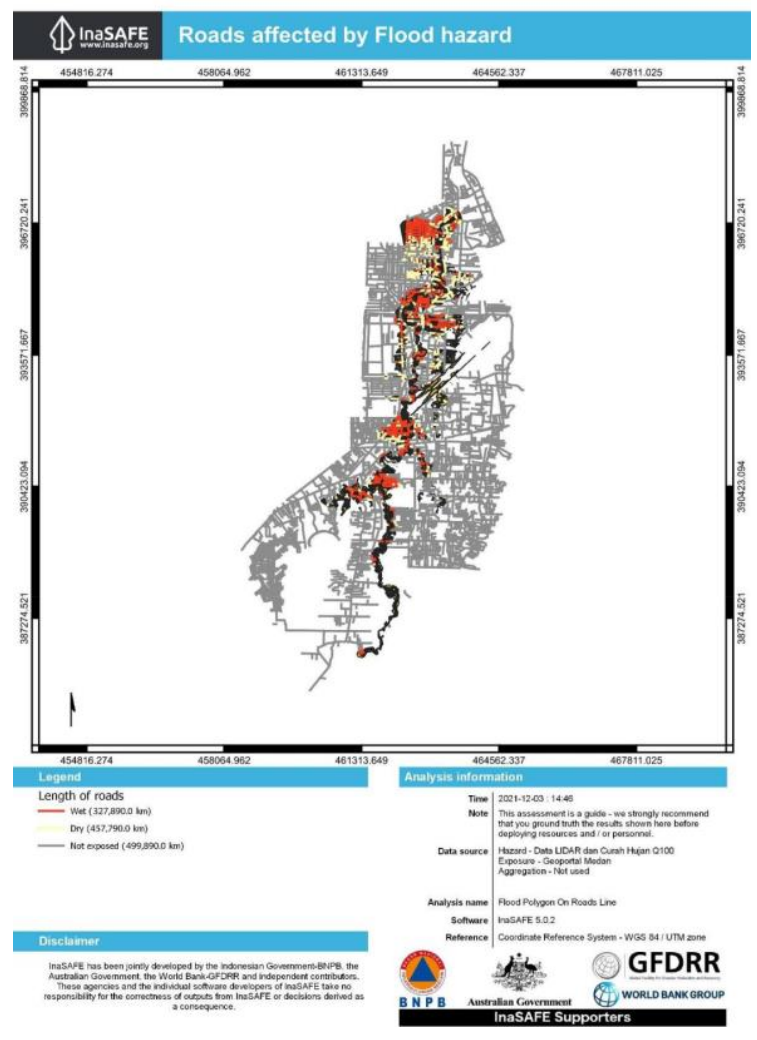

Gambar 20

Jalan Tergenang Banjir Q100

\section{Hasil Wawancara Terhadap Warga Lingkungan Banjir Sungai Babura}

Adapun penelitian ini disertai dengan data pendukung melalui wawancara terhadap warga sekitar melalui pengisian kuisioner yang di jalankan. Pertanyaan kuisioner terlampir pada lampiran I.

Dari hasil kunjungan lapangan didapat data sebagai berikut :

Tabel 2

Hasil Wawancara Terhadap Warga

Lingkungan Banjir Sungai Babura

\begin{tabular}{|c|c|c|c|c|}
\hline \multirow{2}{*}{$\begin{array}{l}\text { Nama } \\
\text { Jalan/Gang/Ruas }\end{array}$} & \multirow[b]{2}{*}{ Kelurahan } & \multirow[b]{2}{*}{ Lingkungan } & \multirow{2}{*}{$\frac{\text { Rumah }}{\text { Tergenang }}$} & Rumah \\
\hline & & & & Ibadah \\
\hline GG SUDIRMAN & Kel. Angrung & Lingkungan I & 16 & \\
\hline \multirow{2}{*}{$\begin{array}{l}\text { JL. MONGONSIDI } \\
\text { BARU I }\end{array}$} & & Lingkungan & & \\
\hline & Kel. Angrung & VII & $\varepsilon$ & \\
\hline \multirow{3}{*}{ JL. MONGINSIDI IV } & & Lingkungan & & \\
\hline & Kel. Angrung & $\mathrm{V}$ & 3 & \\
\hline & & Lingkungan & & \\
\hline \multirow{3}{*}{$\begin{array}{l}\text { GG. MANDOR } \\
\text { KAMPUNG } \\
\text { MANDAILING }\end{array}$} & Kel. Beringin & VI & 70 & \\
\hline & & lingkungan & & \\
\hline & Kel. Darat & III & 10 & 1 \\
\hline \multirow{2}{*}{ GG. DAMAI } & & Lingkungan & & \\
\hline & Kel. Kwala Bekala & III & 78 & \\
\hline GG. JAYA & Kel. Kwala Bekala & Lingkungan & 50 & \\
\hline
\end{tabular}




\begin{tabular}{|c|c|c|c|c|}
\hline & & III & & \\
\hline \multirow[b]{2}{*}{ GG. CAFE } & \multirow[b]{2}{*}{ Kel. Kwala Bekala } & Lingkungan & \multirow[b]{2}{*}{67} & \\
\hline & & III & & \\
\hline \multirow{3}{*}{$\begin{array}{l}\text { NO NAME } \\
\text { JLN. A.H. NASUTION } \\
\text { (JLN. }\end{array}$} & \multirow{3}{*}{ Kel. Kwala Bekala } & Lingkungan & \multirow{3}{*}{89} & \\
\hline & & III & & \\
\hline & & & & \\
\hline \multirow{2}{*}{$\begin{array}{l}\text { TRITURA/JLN. } \\
\text { KARYA }\end{array}$} & \multirow{3}{*}{ Kel. Kwala Bekala } & Lingkungan & \multirow[b]{2}{*}{66} & \\
\hline & & & & \\
\hline JASA) & & III & \multirow[b]{2}{*}{60} & \multirow[b]{2}{*}{1} \\
\hline GG. DAMAI & Kel. Kwala Bekala & Lingkungan II & & \\
\hline GG. JAYA & Kel. Kwala Bekala & Lingkungan II & 90 & \\
\hline GG. PERMAI & Kel. Kwala Bekala & Lingkungan II & 100 & 1 \\
\hline GG. GARU & Kel. Kwala Bekala & Lingkungan I & 8 & \\
\hline \multirow[b]{2}{*}{ GG. KOPI RAYA 4} & \multirow[b]{2}{*}{ Kel. Mangga } & Lingkungan & \multirow[b]{2}{*}{8} & \\
\hline & & VI & & \\
\hline \multirow[b]{2}{*}{ GG. KARET } & \multirow[b]{2}{*}{ Kel. Mangga } & Lingkungan & \multirow[b]{2}{*}{5} & \\
\hline & & V & & \\
\hline \multirow[b]{2}{*}{ JL. KARET 5} & \multirow[b]{2}{*}{ Kel. Mangga } & Lingkungan & \multirow[b]{2}{*}{7} & \\
\hline & & VII & & \\
\hline \multirow{2}{*}{$\begin{array}{l}\text { KOMPLEK BEKALA } \\
\text { ASRI }\end{array}$} & & Lingkungan & & \\
\hline & Kel. Mangga & $\mathrm{V}$ & 9 & \\
\hline & & Lingkungan & & \\
\hline JL. KARET 7 & Kel. Mangga & $\mathrm{V}$ & 11 & \\
\hline & & Lingkungan & & \\
\hline GG. LAPINDO & Kel. Padang Bulan & & 40 & \\
\hline & & VI & & \\
\hline JL. GEREJA KOMP & & Lingkungan & & \\
\hline PAMEN & Kel. Padang Bulan & VI & 30 & \\
\hline & & Lingkungan & & \\
\hline GG. PEMANDIAN & Kel. Padang Bulan & VI & 38 & \\
\hline GG. DIPANEGARA & Kel. Padang Bulan & Lingkungan 6 & 30 & \\
\hline & Kel. Pasar Merah & & & \\
\hline GG. LANDASAN & Barat & Lingkungan I & 20 & \\
\hline GG. HARAPAN & Kel. Petisah Hulu & Lingkungan 7 & 54 & \\
\hline & Kel. Petisah & Lingkungan & & \\
\hline JL. AIRLANGGA & Tengah & III & 5 & \\
\hline & Kel. Petisah & Lingkungan & & \\
\hline JL. AIR LANGGA & Tengah & III & 6 & \\
\hline & Kel. Petisah & Lingkungan & & \\
\hline JL. TUMAPEL & Tengah & III & 4 & \\
\hline & Kel. Petisah & Lingkungan & & \\
\hline JL. TARUMA & & & 5 & \\
\hline & Tengah & III & & \\
\hline & Kel. Petisah & Lingkungan & & \\
\hline GG. SOPAN & & & 7 & \\
\hline & Tengah & III & & \\
\hline JL. KEJAKSAAN & Kel. Petisah & Lingkungan & 8 & \\
\hline
\end{tabular}




\begin{tabular}{|c|c|c|c|c|}
\hline & Tengah & III & & \\
\hline \multirow[b]{2}{*}{ JL. LAPANGAN BOLA } & Kel. Petisah & Lingkungan & & \\
\hline & Tengah & III & 7 & \\
\hline \multirow[b]{2}{*}{ GG. SUUR } & Kel. Petisah & Lingkungan & & \\
\hline & Tengah & III & 5 & \\
\hline \multirow[b]{2}{*}{ S. Babura } & Kel. Petisah & & & \\
\hline & Tengah & Lingkungan I & 8 & \\
\hline \multirow[b]{2}{*}{ JL. CANDI MENDUT } & Kel. Petisah & & & \\
\hline & Tengah & Lingkungan I & 7 & 1 \\
\hline \multirow{2}{*}{$\begin{array}{l}\text { JL. CANDI } \\
\text { BOROBUDUR }\end{array}$} & Kel. Petisah & & & \\
\hline & Tengah & Lingkungan I & 6 & \\
\hline \multirow[b]{2}{*}{ JL. KEBUN BUNGA } & Kel. Petisah & & & \\
\hline & Tengah & Lingkungan I & 7 & \\
\hline \multirow[b]{2}{*}{ GG. PEMANDIAN } & & Lingkungan & & \\
\hline & Kel. Polonia & $\mathrm{VI}$ & 40 & \\
\hline \multirow[b]{2}{*}{ GG. BILAL } & & Lingkungan & & \\
\hline & Kel. Polonia & 10 & 25 & \\
\hline \multirow{3}{*}{ JL. KARYA BERSAMA } & & Lingkungan & & \\
\hline & Kel. Polonia & $\mathrm{V}$ & 10 & \\
\hline & & Lingkungan & & \\
\hline GG. SARI REJO & Kel. Sarirejo & VII & 20 & \\
\hline \multirow[b]{2}{*}{ GG. LANDASAN } & & Lingkungan & & \\
\hline & Kel. Sarirejo & VII & 20 & \\
\hline \multirow[b]{2}{*}{ JL. CINTA KARYA } & & Lingkungan & & \\
\hline & Kel. Sarirejo & VII & 20 & \\
\hline GG. MAWAR & $\begin{array}{l}\text { Kel. Simalingkar. } \\
\text { B }\end{array}$ & Lingkungan $\mathrm{v}$ & 15 & \\
\hline GG. TAMBAK & $\begin{array}{l}\text { Kel. Simalingkar. } \\
\text { B }\end{array}$ & Lingkungan $\mathrm{v}$ & 25 & \\
\hline \multirow[b]{2}{*}{ GG. SADARI } & & lingkungan & & \\
\hline & Kel. Titi Ronte & VII & 20 & \\
\hline \multirow{3}{*}{ GG. ANGKIR } & & lingkungan & & \\
\hline & Kel. Titi Ronte & & 20 & \\
\hline & & VII & & \\
\hline \multirow{2}{*}{ GG. BUDI UTOMO } & & lingkungan & & \\
\hline & Kel. Titi Ronte & VII & 20 & \\
\hline
\end{tabular}

Berikut dokumentasi saat kunjungan lapangan, di komplek pamen padang bulan air pernah menggenang hingga atap rumah warga dimana garis bekas banjir memiliki ketinggian lebih dari 2 meter dari permukaan tanah. Saat kunjungan ke daerah kampong mandailing tempat ibadah yaitu mushola tergenang dikarenakan sangat dekat dengan bibir sungai. Demikian pula saat kunjungan ke wilayah kelurahan petisah hulu ditemukan rumah ibadah yaitu kuil dan mushola sering tergenang banjir dikarenakan lokasinya yang dekat dengan bibir sungai. 


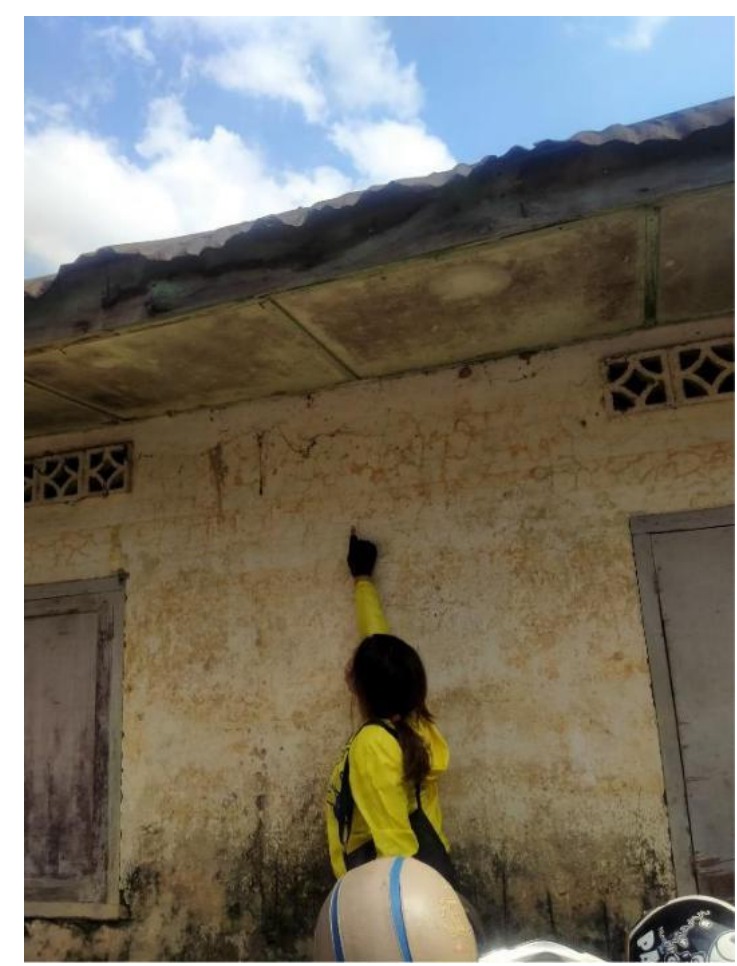

Gambar 21

Dokumentasi Kunjungan Lapangan Di Komplek Pamen Padang Bulan

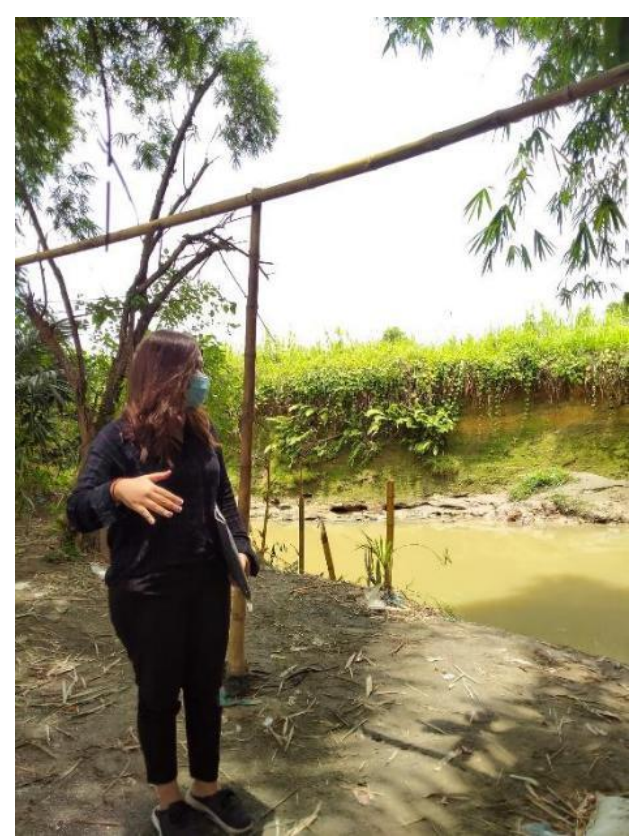

Gambar 22

Dokumentasi Kunjungan Gg Mandailing 


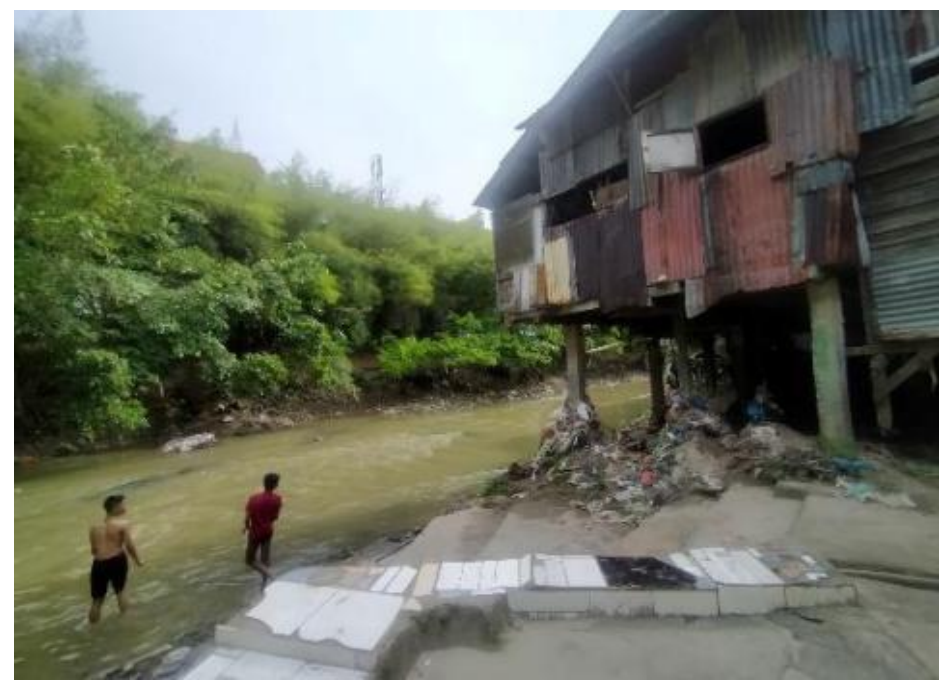

Gambar 23

Dokumentasi kunjungan Gg

Harapan, Petisah Hulu

\section{Analisa Kerugian Banjir}

Dari hasil perhitungan kerugian yang telah dianalisa dalam penelitian Jurnal Teknik Sipil UBL Volume 5 No. 1 April 2014 Analisis Kerugian Akibat Banjir di Bandar Lampung (Sesunan, 2014) diperoleh nilai kerugian banjir dengan menggunakan metode ECLAC dengan menggunakan data Rencana anggaran biaya (RAB) yang ada, maka didapat harga masing-masing Item untuk per meternya sebagai berikut:

Tabel 3

Hasil Analisa Kerugian Banjir Dengan

Metode ECLAC

\begin{tabular}{lllr}
\hline No & Sektor & Sub Sektor & Harga per meter (Rp) \\
\hline I & Perumahan & Rumah Sangat Sederhana & $500.000,00$ \\
\hline & & Rumah Sederhana & $1.000 .000,00$ \\
\hline & Rumah Mewah & $1.500 .000,00$ \\
\hline & Ruko & $1.500 .000,00$ \\
\hline & & Gedung & $2.500 .000,00$ \\
\hline \multirow{2}{*}{ II } & Sektor & Puskesmas & $1.500 .000,00$ \\
& Sosial & & \\
\hline & & Sekolahan & $1.500 .000,00$ \\
\hline & & Tempat Ibadah & $800.000,00$ \\
\hline & & JalanTanah s/d Latasir & $60.000,00$ \\
\hline III & Infrastuktur & Jalan Tanah s/d Onderlaag & $450.000,00$ \\
\hline & & Jalan Tanah s/d Lapen & $100.000,00$ \\
\hline & Jalan Lingkungan Hot Mix & $550.000,00$ \\
\hline & Jembatan beton & $4.000 .000,00$ \\
\hline & Drainase & $1.000 .000,00$ \\
\hline & Dermaga & $1.500 .000,00$ \\
\hline
\end{tabular}


Selanjutnya dilakukan perhitungan antara hasil dari proses Qgis dengan data angka kerugian yang diperoleh dari hasil analisa kerugian banjir dengan metode ECLAC tersebut, sehingga diperoleh data sebagai berikut (Sesunan, 2014).
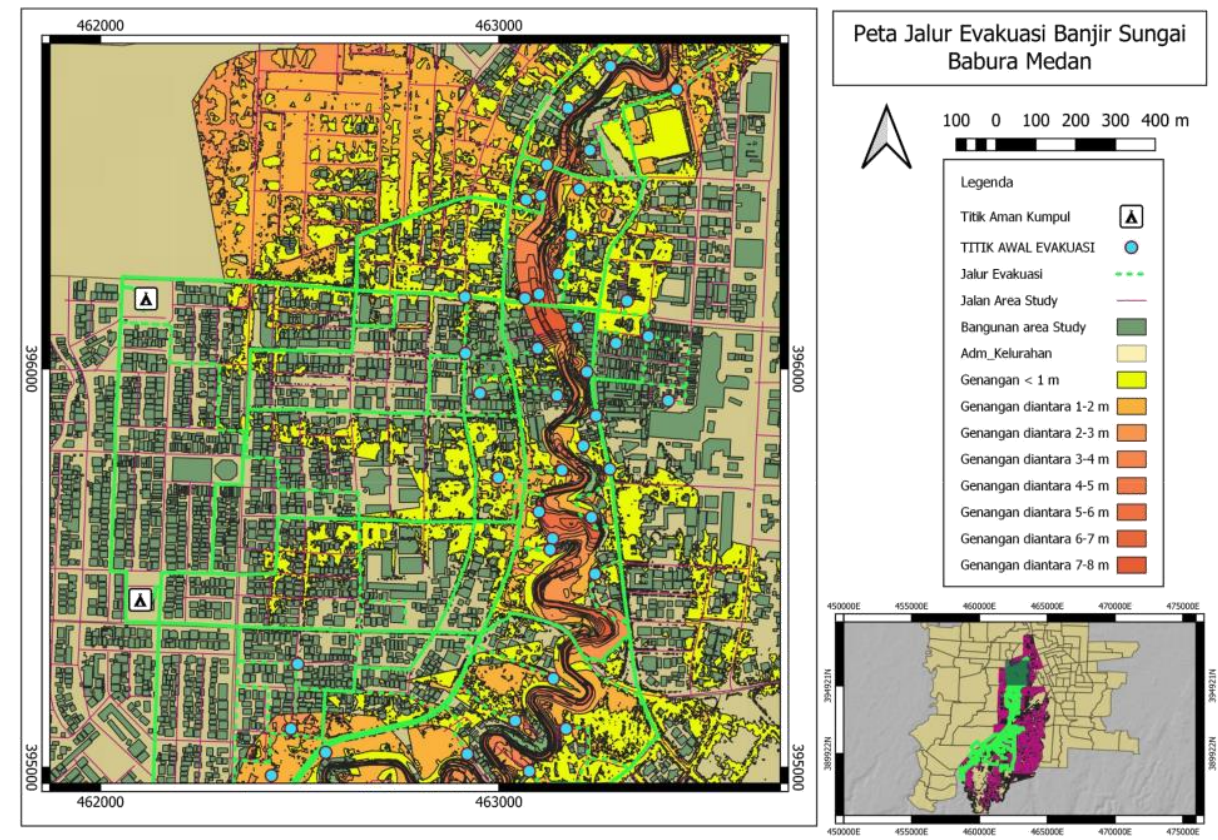

Gambar 24

\section{Jalur Evakuasi Banjir Sungai Babura Medan}

\section{Jalur Evakuasi Banjir}

Dalam menentukan evakuasi banjir penulis menggunakan program QGIS dengan processing tool - Network Analysis - Shortestpath. Dengan proses tersebut dihasilkan jalur evakuasi dengan alur tersingkat menuju titik aman bagi korban saat terjadi bencana banjir. Adapun tambilan dari jalur evakuasi dengan megambil titik awal yang merupakan bagian pinggiran sungai yang menggenangi rumah warga.

\section{Kesimpulan}

Adapun kesimpulan yang diperoleh dari hasil penelitian ini adalah sebagai berikut : 1) Setelah dilakukan perbandingan dari jumlah luasan bangunan yang tergenang akibat banjir dari hasil analisa perbandingan prediksi kerugian banjir tiap periode, yaitu membandingkan jumlah luasan dari tiap jenis tipe bangunan untuk masing-masing periode debit banjir terhadap jumlah genanangan yang diperoleh melalui data kuisioner/wawancara di lapangan diperoleh bahwa angka luasan banjir yang cukup berbeda, seperti yang ditampilkan pada tabel berikut ini. 2) Setelah dilakukan perbandingan dari jumlah luasan bangunan yang tergenang akibat banjir dari hasil analisa antara jenis tipe bangunan terhadap jumlah keseluruhan luasan genangan untuk masing-masing periode debit banjir diperoleh bahwa bangunan yang paling banyak mendapatkan kerugian ialah bagian rumah sederhana yang memiliki luasan diatas $90 \mathrm{~m}^{2}$ dan dibawah $300 \mathrm{~m}^{2}$. 3) Daerah yang tergenang banjir akibat meluapnya Sungai Babura 
Meinarty Sinurat, Ahmad Perwira Mlia, Muhammad Faisal

terdiri dari 17 kelurahan, yaitu Kel. Gedung Johor, Kel. Kesawan, Kel. Kwala Bekala, Kel. Mangga, Kel. Merdeka, Kel. Padang Bulan, Kel. Pangkalan Mansyur, Kel. Pasar Merah Barat, Kel. Petisah Hulu, Kel. Petisah Tengah, Kel. Polonia, Kel. Sarirejo, Kel. Simalingkar. B dan Kel. Titi Ronte. Luas genangan yang paling besar dari data pengukuran terdapat di Kelurahan Polonia sedangkan luas genangan yang paling besar dari data kuisioner terdapat di kelurahan Kuala Bekala. 


\section{BIBLIOGRAFI}

Demir, V., \& Kisi, O. (2016). Flood hazard mapping by using geographic information system and hydraulic model: Mert River, Samsun, Turkey. Advances in Meteorology, 2016. Google Scholar

Hutauruk, T. R., Kusuma, A. R., \& Ningsih, W. (2020). Estimasi Kerugian Ekonomi Akibat Banjir Pada Kawasan Pemukiman Penduduk Di Bantaran Sungai Karang Mumus Kota Samarinda. Jurnal Riset Inossa, 2(1), 47-59. Google Scholar

Irianingsih, I., \& Sukono, S. (2017). Estimasi Nilai Kerugian Dan Premi Asuransi Bangunan Akibat Banjir Sungai Citarum Di Kelurahan Baleendah Bandung. Jurnal Ilmiah Matematika Dan Pendidikan Matematika, 9(1), 79-90. Google Scholar

Isma'il, M., \& Saanyol, I. O. (2013). Application of remote sensing (RS) and geographic information systems (GIS) in flood vulnerability mapping: case study of River Kaduna. International Journal of Geomatics and Geosciences, 3(3), 618627. Google Scholar

Muin, S. F., Boer, R., Meteorologi, F. M., Ilmu Pengetahuan Alam, I. P. B., \& Suharnoto, Y. (2015). Pemodelan banjir dan analisis kerugian akibat bencana banjir di DAS Citarum Hulu. Google Scholar

Santoso, H., \& Taufik, M. (2010). Studi Alternatif Jalur Evakuasi Bencana Banjir Dengan Menggunakan Teknologi SIG di Kabupaten Situbondo. Geoid, 5(2), 118124. Google Scholar

Sesunan, D. (2014). Analisis kerugian akibat banjir di Bandar Lampung. Jurnal Teknik Sipil, 5(1). Google Scholar

Suprajaka, A. F. F., \& Putri, S. N. (2018). Evaluasi Tingkat Kerugian Aset Masyarakat Di Kawasan Bencana Banjir (Studi Kasus: Kecamatan Cengkareng Dan Kecamatan Kembangan). Google Scholar 
Meinarty Sinurat, Ahmad Perwira Mlia, Muhammad Faisal

Ward, P. J., Marfai, M. A., Yulianto, F., Hizbaron, D. R., \& Aerts, J. (2011). Coastal inundation and damage exposure estimation: a case study for Jakarta. Natural Hazards, 56(3), 899-916. Google Scholar

\section{Copyright holder:}

Meinarty Sinurat, Ahmad Perwira Mulia, Muhammad Faisal (2022)

First publication right:

Jurnal Syntax Admiration

This article is licensed under:

(cc) (†) () 